\title{
Are we looking for consumers or critical producers of knowledge in the English classroom? A teaching-learning experience with high school students at the Federal Institute
}

Roberta Barros da Fonseca ${ }^{1}$

\section{RESUMO}

Essa narrativa de ensino tem como principal objetivo compartilhar princípios e ações instrucionais durante as aulas de inglês de duas turmas do ensino médio integrado do Instituto Federal de São Paulo (IFSP), compreendendo o processo como uma oportunidade para reflexão da prática e não como um conjunto de receitas pedagógicas a serem seguidas. As ações aqui relatadas são baseadas no trabalho de Ellis (2008) sobre os princípios de instrução e aquisição de uma segunda língua, fazendo parte do plano de trabalho entregue para CAPES como contrapartida do programa de capacitação para professores de inglês da rede federal CAPES/SETEC/NOVA, em janeiro de 2017.

PALAVRAS-CHAVE: Ensino da língua inglesa. Ensino médio técnico. Atividades instrucionais.

\section{ABSTRACT}

This teaching narrative aims at sharing instructional principles and actions during English lessons in two technical high school classes at the Federal Institute of São Paulo (IFSP), understanding the process as an opportunity for classroom practice reflection and not just a set of pedagogical recipes to be followed. The actions reported here are based on Ellis (2008) principles of instructed second language acquisition, being part of a work plan developed for CAPES as a feedback for the CAPES/SETEC/NOVA ongoing education program for English faculty from the federal network, January 2017.

KEYWORDS: English language teaching. Technical high school. Instructional activities.

\section{Introdução}

A lot of unanswered questions pop up when it comes to teaching English in the federal network and we are challenged to establish connections between different areas of knowledge on a daily basis, trying to make sense and link theory to practice, science to technology, individual to group work. Considering all the subjects the high school students have to face in a technical course and how they struggle, it is also important to consider they are not mature enough to connect knowledge on their own. We are the ones in charge of leading the path. When we realize that a class that got started with forty students reaches the sophomore year with twenty-three kids, we decide something urgent has to be done to ease the pressure they go through. Even though the failing or the dropout students did not come from the English classes, I decided to think my classroom activities over and

\footnotetext{
${ }^{1}$ English teacher at the Federal Institute of São Paulo (IFSP). E-mail: robertafonseca@ifsp.edu.br
} 
come up with something more meaningful, learning from their expectations and interests in order to plan fun classes. Somehow, I felt the students needed a hand to link chunks of knowledge and the English language could be a tool for that. The main goal was to engage the students not only in my classes, but on campus in general, improving social interaction and learning at the same time, helping them to become producers and not simply consumers of knowledge in the English classes. Having participated in CAPES/SETEC/NOVA ongoing education program for English faculty from the federal network in January 2017, I was supposed to develop a work plan for my campus and that is how it all began.

\section{Theoretical guidelines and classroom instructional activities}

According to Ellis (2008), teachers and researchers do not agree how instructional activities facilitate language learning and he calls our attention to the importance of classroom reflection, presenting general principles that can be used in different teaching contexts as "a basis for argument and for reflection and not as a set of prescriptions or proscriptions about how to teach" (ELLIS, 2008, p. 1). In his digest the author points out ten principles to keep in mind while planning an English class and that is how I thought my practice over and (re)designed some instructional activities for the technical high school students at IFSP.

The first principle is related to formulaic speech and rule-based competence in which we empower students to role-play chunks of language in meaningful contexts in such a way that they internalize and use the language afterwards. The author does not give suggestions for classroom activities since the purpose of his brief article is to raise awareness about the principles that improve learning and not hand in instructional activities. After all, teachers are the ones in charge of planning instructional activities according to the students' interests, expectations and needs. For this purpose, I had used conversation practice and role-play with chunks of language several times, but I wanted to go a step further with my students, making more sense with the language they learn and use afterwards. So, I decided to use their favorite TV shows and characters to present these chunks of language and formulaic expressions Ellis (2008) pointed out. First of all, I showed them part of a short sequence in an episode, then I presented the dialogue transcription for 
reading, inviting them to role-play and practice the scene in pairs. Three TV shows were used for these classroom activities, Stranger Things, The Big Bang Theory and Friends. The outcome was quite impressive and students were alert not only to language itself, but intonation, interaction and characters identities as well, really engaging and practicing together.

As far as the second principle goes, the author emphasizes the importance of meaning and not only form, focusing on what to say and not only how to say, suggesting a task-based approach in order to show students that language is a social tool and not a distant object to be studied and memorized. Our students need opportunities to get involved in real communication and not just practice vocabulary lists or grammar exercises. To reach this goal I came up with a task, integrating the four language skills and the use of technology, having the class divided into five groups. The idea was to create a short video with important information to share with freshman students that needed to get familiar with the new academic life. Five topics were introduced for the students to choose: how to enjoy library service on campus; how to enjoy life with a student budget; how to improve studying habits and get ready for exams and presentations; how to use MOOCs such as Khan Academy ${ }^{2}$ to improve math skills and how to keep in shape and have a healthy diet. First of all, we watched several videos in English, working on listening and reading skills. Then, the groups started to look for information related to their topic, creating an outline for their future video and developing language skills in the imperative form as well as vocabulary. After that, students got engaged in speaking and sharing ideas to add on the presentation, working on speaking and writing skills. Finally, they got organized to edit the video with all the information and visual resources, being creative and responsible about the use of technology. It is worth mentioning that during the whole process that lasted six classes and some homework time, I supervised all the steps, offering feedback whenever necessary. Two websites were suggested to create the videos, WikiHow ${ }^{3}$ and WeVideo ${ }^{4}$, but students were free to use other resources and I was impressed with their creativity. Through the task we were able to work on the imperative form of many different verbs, but mostly share meaning and experience with other students, talking about a topic that is

\footnotetext{
${ }^{2}$ Available at https://pt.khanacademy.org

${ }^{3}$ Available at https://www.wikihow.com/Main-Page

${ }^{4}$ Available at https://www.wevideo.com/
} 
relevant for all. The videos were watched and offered a final feedback in class with all the five teams. Later on, we shared with other English classes, focusing on the freshman students.

Regarding the third principle for teaching a language, Ellis (2008) reinforces the importance of focusing on form, suggesting that teachers can provide inductive or deductive grammar activities and communicative tasks to practice specific grammar structures or perform and have feedback. I had used the traditional grammar worksheets, tasks and role-play to focus on form, but for this new work plan I thought things through and presented the online placement tests. My classes had previously taken the TOEIC Bridge exam and were motivated about proficiency tests. We used the website English Level $^{5}$ to get warmed up with the tests focusing on form and the students liked the idea of having immediate feedback and being able to ask questions about the grammar topic they missed or did not score for some reason. We had this activity in the computer lab, but I made myself available for them whenever they had a question on a specific grammar aspect and we were able to tackle individual doubts during the whole process. Different online grammar tests were used later on, guiding students to search and use this kind of learning tool to improve language structure.

As far as the fourth principle goes, Ellis (2008) presents the importance of implicit as well as explicit knowledge. There are different theoretical views regarding how implicit knowledge is developed while learning a foreign language. However, teachers and researchers agree that students need to be involved in a communicative activity in order to develop implicit knowledge. On the other hand, explicit knowledge is related to their performance and researchers also have different views regarding this issue. Among others, the author mentions the interface position (DeKeyser, 1998), arguing "that explicit knowledge can become implicit knowledge providing learners have the opportunity for plentiful communication practice" (Ellis, 2008, p. 3). In order to focus on students' implicit and explicit knowledge, I brought up two different conversation topics to be discussed in class, our daily routine activities and schedule and our movie preferences. Two conversation scripts were introduced and students were able to read and go through all the grammar and vocabulary. In pairs they were supposed to remember some rules or language patterns and

\footnotetext{
${ }^{5}$ Available at http://www.languagelevel.com
} 
share with their partner, figuring out and recalling important information. After that, they were asked to role-play the two conversation scripts, coming up with their own personal questions and figuring out if they had more important things to add. Finally, they were given a chance to role-play their modified conversation and the class learned about other friends' interests and routine activities. This way students were first presented a topic with certain questions and script to follow and then they were able to practice until they were confident enough to add or change things around a bit, testing and monitoring grammar aspects for themselves. Students were particularly engaged to present their own questions and answers to enrich the conversation script and it made more sense for them to practice and use the language afterwards.

For principles number five and six, Ellis (2008) reminds us to reflect about instruction and our own role as language teachers as far as grammatical competence goes. Several studies show that language learning in natural or in classroom settings suggest that we should teach grammar considering the natural processes of acquisition, taking advantage of a task-based approach with no attempt to focus on grammar or focusing the instruction on explicit knowledge and grammar facts in a such a way that students can use their own sequence afterwards while communicating. For these two principles we cannot take our students at the Federal Institute for granted, being sensible to their specific needs and different proficiency levels in high school. In other words, we have to be alert to what kind of input we are providing in our classes in order to make the language comprehensible and available to be used for communication. In order to tackle these principles I asked the students' opinion about having a grammar worksheet and they said it helped a great deal and should be handed out every now and then. After that, we have been enriching our classes with some grammar focus as well. But the author tackles an important question, how can we make sure our students have enough input inside and outside the classroom? In order to suggest opportunities for students to practice the language outside the classroom, I presented a website called Lyrics Training ${ }^{6}$, a place they can find their favorite songs and two game possibilities, the choice or the write mode. While listening to their favorite bands and singers, students are supposed to fill in the blanks, working on their listening and spelling skills. The website offers from beginner to expert level, increasing the

\footnotetext{
${ }^{6}$ Available at https://lyricstraining.com/
} 
number of gaps students are supposed to fill in. For each song they score, grammar aspects are recognized and vocabulary is expanded. Their feedback with this website has been quite impressive, considering that students are not usually motivated to homework assignments.

Considering principle number seven now, Ellis (2008) calls our attention to opportunities for output. After all, learning does not only take place when comprehensible input is offered. Students also need a chance to perform what they have learned and been exposed to. Many researchers have suggested communicative tasks where students can negotiate meanings when communication breakdowns or misunderstandings occur. Considering this specific issue, it is important to balance feedback since students feel more confident and less pressured when help comes from a partner and not directly from the teacher. The teacher can be alert to possible problems and give a final feedback for the whole group.

In order to promote this environment of performance in the classroom, I used the conversation topics and scripts I mentioned before where students had the possibility to practice and add their own questions and answers afterwards. However, the foreign language classroom brings up a particular problem, communication does not seem to be so urgent since they can count on code-switching every time they run into a misunderstanding, figuring out the solution in Portuguese. The situation in second language acquisition is different, considering that not all students speak the same first language and are forced to negotiate meaning and reach the communicative goal. So, besides this roleplay activity performed in the classroom where students follow the script and change things around later on, I created an English Club on campus. Students do not have to sign up and it is not for extra credit, it is just another opportunity for practicing English with other students on campus and being able to have a more realistic environment for conversation. Not many kids come to the club, but it has been a start to offer a chance to speak English for one hour, meeting other high school students and under-graduate students as well. The idea for the one hour English Club in the main lobby with no specific topic to discuss, only to interact in the foreign language boils down to principle number eight mentioned by Ellis (2008, p. 4), "the opportunity to interact in the second language is central to developing second language proficiency". With such social interaction students are able to negotiate meaning, use discourse markers and practice the language they have 
been exposed to, learning about other people's interests and getting engaged in real conversation practice. The English teacher is available during the whole time, but the participants only use English to negotiate meaning and straighten things out.

For principle number nine, the author argues that instruction needs to be analyzed, considering the individual differences we have in our classes. This is very important in the federal network since we get students with completely different proficiency levels and we need to plan a class that is relevant for all, not leaving anyone behind and at the same time not making it dull for others. The author suggests a "flexible teaching approach involving a variety of activities" (Ellis, 2008, p. 5). It all boils down to getting to know our students' interests in order to foster different and more meaningful activities to practice and use English, understanding that speaking another language does not mean we have to ban our own linguistic code or culture. The new language only represents a social tool that can be used with more autonomy to have access to academic, technological and cultural information about other parts of the globe. In order to do so we need to constantly question and analyze the quality of our teaching, making sure students are motivated and productive with the activities we bring to class. As the author points out it is quite rare that students bring motivation to the classroom on their own.

The last principle he mentions is related to assessment, analyzing free as well as controlled production. For this purpose, we have been using all the activities mentioned in this teaching narrative, from grammar worksheets to group presentations and oral production. Along with all these new activities involving TV shows, songs, games and tasks, the reading assignments were not taken for granted and students were able to take the university entrance sample tests as well. Students are aware of the rubrics for each activity and they have different possibilities to score in class. For each activity students are also encouraged to reflect on their own learning process, figuring out what they have missed in one activity or the other. The best strategy for that is to set up ground rules for the assessment process and at the same time listen to the students, showing them that it all about team work and we can learn from others and from our mistakes as well. I still find students who struggle with anxiety whenever they have to face an exam in the federal network. In order for them to value the learning journey and not only the finish line with 
the final score, I introduced Quizlet Live ${ }^{7}$ to assess verb aspects and other grammar topics. With the live game in class and using their cell phones, students started appreciating the learning path, especially because when they miss something they keep going back and starting over which is not considered a big deal at all. They have fun during the whole review process and do not blame or judge others for not scoring. The game presents mistakes as part of the learning path. Another great advantage of using this live game tool is group interaction. Since the teams are randomly chosen by the game, students have the opportunity to walk around the classroom, interacting and talking to everyone. To give an idea of the finish line perspective for the same grammar assessment, I also presented Kahoot ${ }^{8}$ and the students did not have as much fun. This other online game offers a podium with the best three scores and students understand how important the learning process is, comparing both games in the classroom. In others words, formal and informal assessment happen in order to improve language proficiency, reinforcing that we learn a great deal from our mistakes.

\section{Final remarks}

The main goal of sharing this teaching narrative was not to offer a set of classroom activities to be used in the English classroom, but to raise awareness to the importance of getting to know our students in order to plan more meaningful classes. We need to be suspicious of routine instructional activities that have been designed kilometers away from our teaching environment. Our high school students have a lot to share and they bring their own cultural values to class, mentioning their favorite movies, TV shows and songs and English is part of all that. As teachers, we can expand and show them other perspectives, movies they have not seen or songs they have not listened to, but we cannot take their contributions for granted while planning our classes. This constant information exchange can foster better and more meaningful classroom activities, improving social interaction and motivation. We are the ones in charge of planning and questioning classroom procedures and instructional activities, changing and moving forward with the new students we get every year. Along with the English textbooks we receive to enrich our

\footnotetext{
${ }^{7}$ Available at https://quizlet.com/pt-br

${ }^{8}$ Available at $\underline{\text { https: } / / \text { kahoot.com/ }}$
} 
classes with reading and university entrance sample tests, we also need to come up with activities that empower students to work on their own.

Considering all the aspects mentioned here, it is certainly a challenging job to teach English as a foreign language in the federal network in Brazil. Even though we can improve our teaching when we theorize our own practice in teaching narratives, experience reports or action-research projects (ALARCÃO, 2011; DÖRNYEI, 2007), we need to figure out a way to help our students dominate the English linguistic code and not to be dominated or controlled by it (RAJAGOPALAN, 2013). In order to tackle, question and investigate English teaching policy in Brazil, we have to frame our own social and historical environment, not simply assimilating what others have previously prescribed as a teaching routine or suggestions for activities. In other words, we have to study and analyze different theories, but get distant from mainstream trends or teaching recipes, theorizing our own teaching reality. In doing so, besides theorizing our daily practice, we help our students become more critical while learning and using a new language. Rajagopalan (2013, p. 159) argues that we have "to consider what are the reasons Brazilian citizens need to learn the English language nowadays. And, more important than that, in what situations their knowledge of the language will be put to proof."

To wrap up this brief teaching narrative I suggest we organize more study and research groups in our communities, reading different studies and bridging the gap between theory and our own teaching practice. Dörnyei (2007, p. 16) mentions McKay (2006, p.1), saying that "research contributes to more effective teaching, not by offering definite answers to pedagogical questions, but rather by providing new insights into the teaching and learning process". Suggesting a critical pedagogy, Brown (2000, p. 445) also highlights that we are not simply English teachers, our role is much more complex than that. We "are agents for change in a world in desperate need of change: change from competition to cooperation, from powerlessness to empowerment, from conflict to resolution, from prejudice to understanding."

\section{REFERENCES}

ALARCÃO, Isabel. Professores reflexivos em uma escola reflexiva. 8 ed. São Paulo: Cortez, 2011. 
BROWN, H. Douglas. Teaching by principles. An interactive approach to language pedagogy. 2 ed. White Plains, NY: Longman, 2000.

DÖRNYEI, Zoltán. Research Methods in Applied Linguistics: Quantitative, Qualitative, and Mixed Methodologies. Oxford: Oxford University Press, 2007.

ELLIS, Rod. Principles of Instructed second language acquisition. CAL Digest, 2008. Available at:

<http://www.actiondyslexia.co.uk/downloads/Principlesofsecondlanguageacquisition.pdf>

RAJAGOPALAN, Kanavillil. Política de ensino de línguas no Brasil: história e reflexões prospectivas. In: MOITA LOPES, Luiz Paulo da (Org.). Linguística Aplicada na modernidade recente. Festschrift para Antonieta Celani. São Paulo: Parábola Editorial, 2013. p. 143-161.

Data de submissão: 20/08/2018. Data de aprovação: 05/11/2018. 